\title{
上肢挙上角と脊柱彎曲角との関係 \\ 一健常成人における検討一 \\ Arm Elevation Angle and Spinal Curvature in Healthy Adults
}

\author{
甲斐 義浩1）村田 伸2)＼cjkstart堀江 淳2) \\ YoshiHIRo KAI, RPT, MS ${ }^{1)}$, SHIN MURATA, RPT, PhD²), JUN HORIE, RPT, MS ${ }^{2)}$ \\ 1) Technical School of Medical and Welfare Ryokuseikan: 1428-566 Nishishin-machi, Tosu-shi, Saga 841-0074, Japan. \\ TEL +81 942-84-5100 \\ 2) Faculty of Rehabilitation Science, Nishikyushu University
}

Rigakuryoho Kagaku 25(1): 19-22, 2010. Submitted Jul. 28, 2009. Accepted Aug. 25, 2009.

ABSTRACT: [Purpose] In this study, we investigated the relationship between arm elevation angle and spinal curvature (thoracic kyphosis and lumbar lordosis) in healthy adults. [Subjects] The subjects were 12 healthy adult males, average age 23.6 \pm 5.5 years. [Method] We measured thoracic kyphosis and lumbar lordosis angles with the arms in 5 positions, at the sides, raised at $90,120,150^{\circ}$ and the maximum elevation, and compared the results of each elevation. [Results] We found that at $150^{\circ}$ and maximum elevation the thoracic kyphosis angle showed a significant reduction compared to elevations of $120^{\circ}$ or less, and the lumbar lordosis angle was significantly increased compared to arms at the sides. Moreover, this increase in lordosis angle showed a generally linear relation to the arm elevation angle. [Conclusion] The relationship between arm elevation and spinal curvature was one in which the lumbar lordosis angle increased linearly with arm elevation, and at elevations of $150^{\circ}$ and above, in addition to lumbar lordosis, thoracic kyphosis decreased significantly, suggesting a mutual contribution from the thoracic and lumbar spines in arm elevation movement.

Key words: arm elevation angle, thoracic kyphosis angle, lumbar lordosis angle

要旨：〔目的〕本研究では，健常成人男性における上肢挙上角と脊柱彎曲角（胸椎後彎角および腰椎前彎角）との 関係について検討した。【対象〕健常成人男性 12 名（平均年齢 $23.6 \pm 5.5$ 歳）。〔方法〕上肢下垂位， $90^{\circ}, 120^{\circ}, 150^{\circ}$, 最大挙上位の 5 肢位における胸椎後彎角と腰椎前彎角を計測し, 各挙上肢位で比較した。〔結果〕胸椎後彎角は, 上 肢下垂位から $120^{\circ}$ 挙上位までと比較して $150^{\circ}$ 挙上位と最大挙上位で有意な減少を示した。腰椎前彎角は，上肢下垂 位と比べ $150^{\circ}$ 挙上位以上で有意な増加を認めた。また, その増加の推移は上肢挙上角の増加に伴って概站直線的に 増加する傾向を示した。〔結語〕上肢挙上運動と脊柱彎曲角との関係は, 挙上運動に伴って腰椎前彎角が概放直線 的に増加し, $150^{\circ}$ 挙上位以上で腰椎前彎に加えて胸椎後彎角が有意に減少することで, 上肢挙上運動に胸腰椎が相 互的に貢献することが示唆された。

キーワード：上肢挙上角, 胸椎後彎角, 腰椎前彎角

1) 医療福祉専門学校緑生館 理学療法学科：佐賀県鳥栖市西新町1428-566（玄841-0074）TEL 0942-84-5100

2) 西九州大学 リハビリテーション学部

受付日 2009年7月28日＼cjkstart受理日２009年8月25日 


\section{I. 緒 言}

従来から, 上肢挙上運動のメカニズムは, 肩甲骨と上 腕骨の動きを中心にさまざまな研究が行われてきた ${ }^{1-3)}$ 。 $\operatorname{Codman}^{1)}$ は, 上肢挙上運動時に起こる肩甲骨と上腕骨の 連動した動きを scapulohumeral rhythm と呼び，さらに $\left.\mathrm{Inman}^{2}\right)$ は，この上腕骨と肩甲骨の運動は挙上運動全体 を通してみると, 概ね 2: 1 の割合で起こることを明ら かにした。これら先行研究において, 肩甲上腕関節の分 析が優先されて行われてきた背景には, 臨床上肩関節の 障害の多くが肩甲上腕関節を中心に生じるためと考え られる。

一方, 上肢挙上運動は, これら肩甲骨と上腕骨の運 動のみによって成り立っているものではなく, 体幹の 動きも共同して作用することが確認されている ${ }^{4-11)}$ 。 Lanz $5^{6)}$ は, 肩甲骨の回旋が体幹の伸展運動を介して 上肢挙上を補助していると述べている。また, Edmonston ら 9) やTheodoridis ら ${ }^{10)}$ は, 胸椎の運動制限は上肢挙上の 機能的制限と密接に関係することを報告している。さ らにCrosbie ら ${ }^{11)}$ は, 肩甲上腕関節の運動制限によって, 胸椎は代償運動を強いられることを示唆している。こ のように, 上肢挙上運動と体幹運動との関係は, 特に 胸椎の伸展運動に注目した研究が数多く行われてきた。 しかしながら, 上肢挙上運動には胸椎のみならず腰椎 の運動も関与することが推測されるが, これら胸腰椎 の複合的な作用についての検討は不十分である。よっ て, 肩甲上腕関節に発生する機能障害を理解する上で も，上肢挙上運動に共同して作用する胸椎および腰椎 の運動変化を明らかにすることは臨床上有益である。

そこで本研究では, 健常成人男性を対象に上肢挙上 運動に伴う胸椎後彎角と腰椎前彎角の変化を分析する ことにより，上肢挙上角と矢状面上の脊柱彎曲角との 関係について検討した。

\section{II. 対象と方法}

\section{1. 対象}

対象は，健常成人男性 12 名とした。いずれも上肢や 体幹に疼痛や不安感などの既往はなかった。年齢は平 均 $23.6 \pm 5.5$ 歳, 身長は平均 $169.7 \pm 3.8 \mathrm{~cm}$, 体重は平均 $65.4 \pm 6.7 \mathrm{~kg}$ であった。これら被験者には, 研究の目的 と方法を十分に説明し, 同意を得た上で研究を開始した。

2. 方法

測定肢位はいす座位とし，右側の上肢を矢状面上で
挙上させた。測定は上肢下垂位, $90^{\circ}, 120^{\circ}, 150^{\circ}$, 最 大挙上位の 5 肢位とし, 各上肢挙上角で上肢を静止さ せ，インデックス社製のスパイナルマウスを用いて胸 椎後彎角および腰椎前彎角を測定した。このスパイナ ルマウスは, 春柱の彎曲角度を被験者背部の体表から 測定できる機器であり, 得られた測定值の信頼性につ いては既に確認されている ${ }^{12)}$ 。測定は，各上肢挙上角 保持時の第7頸椎から第3 仙椎までを, スパイナルマウ スのセンサー部を移動させて測定した。今回分析に使 用したのは，第 1 胸椎から第 12 胸椎までの上下椎体間 がなす角度の総和である胸椎後彎角, 第 1 腰椎から第 5 腰椎までの上下椎体間がなす角度の総和である腰椎前 彎角である。それぞれ 3 回の測定から得られた平均值 を胸椎後彎角および腰椎前彎角とした。なお, 各測定 順序はランダム化した。

統計処理は反復測定分散分析法およびBonferroniの多 重比較検定を採用し, 危険率 5\%未満を有意差ありと判 定した。

\section{III. 結 果}

各上肢挙上角における胸椎後彎角の平均值 (mean \pm SE）は, 下垂位 : $27.5 \pm 2.0^{\circ}, 90^{\circ}$ 挙上位 : $26.9 \pm 2.3^{\circ}$, $120^{\circ}$ 挙上位: $24.9 \pm 2.2^{\circ}, 150^{\circ}$ 挙上位: $21.3 \pm 2.1^{\circ}$, 最大 挙上位: $16.8 \pm 1.7^{\circ}$ であった。 $150^{\circ}$ 挙上位と最大挙上位 の胸椎後彎角は, 上肢下垂位, $90^{\circ}$ 挙上位および $120^{\circ}$ 挙

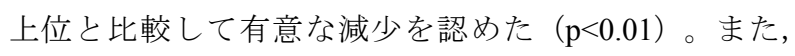
最大挙上位の胸椎後彎角は, $150^{\circ}$ 挙上位と比べ有意な 減少を認めた（ $<0.01 ，$ 表 1$)$ 。

各上肢挙上角における腰椎前彎角の平均值 (mean \pm SE）は, 下垂位 : $1.3 \pm 4.2^{\circ}, 90^{\circ}$ 挙上位 : $2.3 \pm 4.3^{\circ}, 120^{\circ}$ 挙上位: $2.9 \pm 4.2^{\circ}, 150^{\circ}$ 挙上位 : $4.0 \pm 4.4^{\circ}$, 最大挙上 位: $6.3 \pm 4.6^{\circ}$ であった。 $150^{\circ}$ 挙上位の腰椎前彎角は, 下 垂位と比べ有意な増加を認めた $(\mathrm{p}<0.05)$ 。また, 最大 挙上位の腰椎前彎角は, 下垂位から $120^{\circ}$ 挙上位と比べ 有意な増加を認めた $(\mathrm{p}<0.01)$ 。腰椎前彎角増加の推移 は上肢挙上角の増加に伴って概ね直線的に増加する傾 向を示した（表1）。

\section{IV. 考 察}

本研究では，健常成人男性における上肢挙上角と春 柱彎曲角（胸椎後彎角および腰椎前彎角）との関係に ついて検討した。分析の結果, 胸椎後彎角は上肢下垂 位から $120^{\circ}$ 挙上位までは有意な変化を示さなかったが, 
表1 上肢挙上運動における胸椎後彎角および腰椎後彎角の変化

\begin{tabular}{lrrrrr}
\hline & 下垂位 & \multicolumn{1}{c}{$90^{\circ}$} & \multicolumn{1}{c}{$120^{\circ}$} & $150^{\circ}$ & \multicolumn{1}{c}{ 最大挙上位 } \\
\hline 胸椎後彎角 & $27.5 \pm 2.0^{\circ}$ & $26.9 \pm 2.3^{\circ}$ & $24.9 \pm 2.2^{\circ}$ & $\left.\left.\left.21.3 \pm 2.1^{\circ} * * 1\right) 2\right) 3\right)$ & $\left.\left.\left.16.8 \pm 1.7^{\circ} * * 1\right) 2\right) 3\right)$ \\
腰椎前彎角 & $1.3 \pm 4.2^{\circ}$ & $2.3 \pm 4.3^{\circ}$ & $2.9 \pm 4.2^{\circ}$ & $\left.4.0 \pm 4.4^{\circ} * * 1\right)$ & $\left.\left.\left.6.3 \pm 4.6^{\circ} * * 1\right) 2\right) 3\right)$ \\
\hline
\end{tabular}

1) 下垂位と比較して有意差あり， ${ }^{2} 90^{\circ}$ と比較して有意差あり， ${ }^{3)} 120^{\circ}$ と比較して有意差あり

*: $\mathrm{p}<0.05 * *: \mathrm{p}<0.01$

$150^{\circ}$ 挙上位以上では有意な胸椎後彎角の減少が認めら れた。一方, 腰椎前彎角は, $150^{\circ}$ 挙上位以上で有意な 増加を認め, 最大挙上位にて最も増加を示した。また, その増加の推移は上肢挙上角の増加に伴って概ね直線 的に増加する傾向を示した。このことから, 上肢挙上 運動と脊柱彎曲角との関係は, 挙上運動に伴い腰椎前 彎角が概ね直線的に増加し， $150^{\circ}$ 挙上位に達すると腰 椎前彎に加えて胸椎後彎角の減少が出現することが示 唆された。

先行研究 ${ }^{1,2)}$ によると, 上肢挙上運動に伴う上腕骨と 肩甲骨の動きは $2: 1$ の割合で生じるが，挙上 $120^{\circ}$ 超 えると相対的に肩甲骨主体の挙上運動が行われること が明らかにされている。また, 上田ら ${ }^{13)}$ は上肢挙上時の 体幹アライメントについて, 挙上 $150^{\circ}$ 以上で有意な胸椎 伸展運動が起こることを述べている。さらに塚本 ${ }^{14)}$ は, 上肢挙上時の胸椎後彎角をX 線撮影により計測し, 最大 挙上位 $\left(180^{\circ}\right)$ において胸椎後彎角が最も減少したこと を報告している。本研究結果においても，150挙上位と 最大挙上位の胸椎後彎角は, 上肢下垂位から $120^{\circ}$ 挙上位 と比較して有意な減少を示した。これらのことより, 上 肢挙上運動と胸椎後彎角との関係は, $120^{\circ}$ 挙上位までは 上腕骨と肩甲骨の動きが主体となるため胸椎後彎角の 変化は僅かであるが, $120^{\circ}$ 以上は肩甲骨主体の動きに胸 椎伸展運動が連動して作用することで上肢挙上運動に 貢献することが示唆された。

腰椎前彎角は, 上肢下垂位と比べ $150^{\circ}$ 挙上位以上で 有意な増加を認め, 最大挙上位において最も増加を示 した。Kapandi ${ }^{15)}$ や花村ら ${ }^{16)}$ は, 上肢挙上運動における 腰椎前彎の重要性を述べ, 特に挙上 $150^{\circ} よ り$ 腰椎前彎 角の増大が起こることを示している。一方, 塚本 ${ }^{14)}$ は, $150^{\circ}$ 以上の上肢挙上に伴って起こる胸椎の伸展運動は, 腰椎前彎の増大によるものと報告している。本研究結 果においても, $150^{\circ}$ 挙上位以降に有意な腰椎前彎角の 増加を認め, これら先行研究を支持するものであった。 また, 上肢挙上運動に伴う腰椎前彎角の推移は, 挙上 角が増すとともに概ね直線的な増加を示し, 上肢挙上 運動の全般に渡って共同的に作用する可能性が示唆さ
れた。

以上の結果より, 上肢挙上運動に対して胸腰椎は相 互的関係を示すことが明らかとなった。このことから， 肩関節の運動障害に対する理学療法は, 肩甲上腕関節 や肩甲胸郭関節のみならず胸腰椎の相互作用に留意す る必要性が示唆された。ただし, 本研究の対象者数は 少なく, かつ健常成人男性に限定したため, 今回の結 果が円背姿勢などの春柱アライメント変化を来たしや すい中高齢者にも該当するとは限らない。今後は，本 研究結果をさらに検証するため, 対象範囲を拡大する ことで, 高齢者でも今回の結果が当てはまるのか否か について検討する必要があろう。

\section{引用文献}

1) Codman EA: The Shoulder. Thomas Todd, Boston, 1934.

2) Inman VT, Saunder JB, Abbott LC: Observations on the function of the shoulder joint. J Bone Joint Surg, 1944, 26: 1-30.

3) Saha AK: Dynamic stability of the glenohumeral joint. Acta Orthop Scand, 1971, 42: 491-505.

4) 田中直史, 大沢正秀, 大槻信吾 - 他 : 肩甲胸郭関節の加齢に よる動きの低下と上肢運動連鎖としての機能について. 別冊 整形外科, 1999, 36: 13-18.

5) Cailliet R: 肩の痛み. 萩島秀男（訳）, 医歯薬出版, 東京, 1995, pp1-50.

6) Lanz TV, Wachsmuth W: Praktische Anatomie, Arm. Verlag von Julius Springer, Berlin, 1935, pp49-107.

7) Crawford HJ, Jull GA: The influence of thoracic posture and movement on range of arm elevation. Physiother Theory Pract, 1993, 9: 143-148.

8) Stewart SG, Jull GA, Ng JK-F, et al.: An initial analysis of thoracic spine movement during unilateral arm elevation. J Man Manip Ther, 1995, 3: 15-20.

9) Edmondston SJ, Singer KP: Thoracic spine: anatomical and biomechanical considerations for manual therapy. Man Ther, 1997, 2: 132-143.

10) Theodoridis D, Ruston $S$ : The effect of shoulder movements on thoracic spine 3D motion. Clin Biomech, 2002, 17: 418-421.

11) Crosbie J, Kilbreath SL, Hollmann L, et al.: Scapulohumeral rhythm and associated spinal motion. Clin Biomech, 2008, 23: 184-192. 
12) Mannion AF, Knecht $K$, Balaban G, et al.: A new skin-surface device for measuring the curvature and global and segmental ranges of motion of the spine: reliability of measurements and comparison with data reviewed from the literature. Eur Spine J, 2004, 13(2): 122-136.

13）上田泰之, 浦辺幸夫, 大林弘宗・他 : 若年者と高齢者におけ る上肢挙上時の体幹アライメントの違い. 体力科学, 2008,
57: 485-490.

14) 塚本芳久: 上肢前方挙上時における脊柱の動きに関する動態 学的研究一肩甲帯との関係一. リ八医学, 1990, 27(6): 453-458.

15) Kapandji IA: The physiology of the joints. Churchill Livingstone, New York, 1982, pp1-71.

16) 花村達夫, 中山慎一郎, 高岸直人 - 他 : 肩関節可動域と挙上 運動の分析．肩関節，1977, 1: 1-4. 